23 Caspi A, Hariri AR, Holmes A, Uher R, Moffitt TE. Genetic sensitivity to the environment: the case of the serotonin transporter gene and its implications for studying complex diseases and traits. Am J Psychiatry 2010; 167: 509-27.

24 Hariri AR, Mattay VS, Tessitore A, Kolachana B, Fera F, Goldman D, et al Serotonin transporter genetic variation and the response of the human amygdala. Science 2002; 297: 400-3.
25 Surguladze SA, Elkin A, Ecker C, Kalidindi S, Corsico A, Giampietro V, et al. Genetic variation in the serotonin transporter modulates neural system-wide response to fearful faces. Genes Brain Behav 2008; 7: 543-51.

26 Neumeister A, Konstantinidis A, Stastny J, Schwarz MJ, Vitouch O, Willeit $\mathrm{M}$, et al. Association between serotonin transporter gene promoter polymorphism (5HTTLPR) and behavioral responses to tryptophan depletion in healthy women with and without family history of depression. Arch Gen Psychiatry 2002; 59: 613-20.

\section{Poems \\ by doctors}

\title{
The Great Asylums of Scotland
}

\section{Tom Pow}

The great asylums of Scotland, cloistered like the proud abbeys we tore down brick by brick. Yet harder to love. They docked at the edge of our towns like relations with whom we felt ill at ease. Ones who kept themselves to themselves. Their farms. Their laundries.

Their water supplies. We stand in their portals, our eyes drawn down the tree-lined avenues to the prospect of distant hills. Country houses? Hydros? Oh, what shall we do with them? the great asylums of Scotland, still with us, as keen to serve as the day they were built.

A fleet for their time they set out, freighted with hope and grand design. Look at them now, scuttled on the ocean floor. Light floods them. Along their corridors, doors flap open on empty cabins with nothing to hide. In attic rooms the sky's light pours over

a tide-wrack of maps, plans, records - a grid to lay over a waste of rage, grief, anger and pain. None of that will make a cairn. In these, the great asylums of Scotland, always it is evening about to fall.

The heavy doors are closing in on us all. and the counting begins. But coming through the frayed web of darkness are slants of light: greenness, firstness, hope. What is to be done with a two-faced legacy such as this? Multi-occupancy - that's the answer! Flatpacks to the gentlemen's quarters, IKEA to the boardrooms. Four by fours draw up before the great asylums now. They're made for them, framed by chestnut trees, like adverts. Inside the auction hall the stillness of graveyards, the discretion of private affairs. Oh how beautiful are the crafted dovetailes in the wardrobes no one wants. They sulk like small monuments history has ignored. So much gloom. 'I wouldn't want any of it in my house,' someone says. 'Not knowing where it's come from.' As if objects soak up instability

like nicotine. If so, not only so for writing up the staircase in Crichton Hall are oak leaves, carved not by craftsmen from Antwerp, but by men traipsing over winter fields from Dalton using a water pipe as guide. Run your hands over the leaves and you'll feel their approval for their new asylum. Though of the mad, little could be salvaged not one knitted pullover, not one apron for these craftsmen, the trade in lunacy was a godsend. The melancholy we mourn they transfromed into bread, milk, sunlight.

Tom Pow was writer in residence at the Edinburgh International Book Festival 2001-2003 and poet in residence at StAnza, Scotland's poetry festival. He is senior lecturer at Glasgow University, Crichton Campus, Dumfries. This poem is from his collection Dear Alice Narratives of Madness (Salt, 2008), a poetic response to the Crichton Royal, Dumfries. Reproduced with permission from Salt Publishing Limited. (c) Tom Pow 